\title{
PERAN PENGUKURAN, STANDARDISASI, PENGUJIAN DAN JAMINAN MUTU (MSTQ) DALAM USAHA PENINGKATAN MUTU
}

\author{
Ir. Setyodewati, M.Eng.Sc
}

\begin{abstract}
Measurement, Standardization, Testing and Quality Assurance (MSTQ) have important role in the recent development of industry, science and technology. Those four elements are interrelated, thus are measurement without the accepted standard developed through National Standardization System is meaningless. Recently, most of calibration activities are carried out by private sector and their location are concentrated in Jakarta and West Java. Most of them are focusing their calibration activities to the needs of their parent organizations, and the only small number of them also provides their calibration services to external customers. On the other hand, the number of testing laboratories increase faster as demand from the government for exported or imported products shall be tested by accredited testing laboratories as the application of mandatory national standards (SNI). Location testing laboratories widely spread in the country and their activities depend on the commodities of the region, for example, in the region those produce tea or coffee, there will be testing laboratories for tea and coffee. Scope of activities of calibration laboratories also focused on the measurement of mass, temperature, dimensional as most of Indonesian industries use the kind of measuring instruments for their processes.
\end{abstract}

Keywords: MSTQ, calibration laboratories, testing laboratories.

\section{PENDAHULUAN}

Sejak dicanangkannya rencana pemerintah untuk siap tinggal landas menuju era industrialisasi pada awal abad 21, banyak sudah usaha yang telah ditempuh untuk mewujudkan rencana tersebut. Semua usaha telah menampakkan hasil, misalnya mekarnya industri dalam negeri serta meningkatnya ekspor produkproduk manufaktur. Hasil yang telah diperoleh dengan susah payah itu perlu dan harus dimantapkan serta ditingkatkan, dan mengenai pemantapan serta peningkatan produksi, tidak dapat tidak, mutu akan dipermasalahkan terutama mutu produk industri dalam negeri.

Mutu merupakan kekuatan pokok produk industri yang menentukan kesanggupan dan ketangguhannya untuk menghadapi makin kerasnya persaingan antara sesama produsen dan makin meningkatnya tuntutan konsumen. Untuk menjaga dan meningkatnya mutu produk industri, diperlukan peranan pengukuran, standardisasi, pengujian dan jaminan mutu (MSTQ - Measurement, Standardization, Testing, and Quality). Peran pengukuran melalui kalibrasi, standardisasi dan pengujian, dan untuk jaminan mutu diperlukan sistem penilaian kesesuaian yang mencakup kemampuan teknis dan manajemen.

Peranan kalibrasi tidak terlepas dari ketertelusuran pengukuran yaitu dengan melalui kalibrasi ketertelusuran pengukuran dapat di lacak ke satuan SI yang artinya jaminan atas hasil dari pengukuran dan atau pengujian dapat dipertanggung jawabkan. Dalam ketertelesuran terdapat Institusi Metrologi Nasional (National Metrology Institution - NMI) sebagai suatu institusi yang mengelola standar fisik nasional di suatu negara. NMI dapat diakui secara internasional jika institusi tesebut dapat membuktikan bahwa peralatan standar yang dikelolanya tertelusur ke satuan sitem internasional atau SI. Salah satu cara untuk menilai kompetensi ini dengan melakukan evaluasi terhadap NMI tersebut. Di Indonesia sebagai NMI adalah Pusat Penelitian Kalibrasi, Instrumentasi dan Metrologi (Puslit KIM) - LIPI yang ditunjuk sebagai Pengelolaan Teknis IImiah Standar Nasional Satuan Ukuran (SNSU) dalam Kepres No. 79 tahun 2001 tentang Komite Standar Nasional untuk Satuan Ukuran. Puslit $\mathrm{KIM}$ ini telah dievaluasi melalui akreditasi oleh Komite Akreditasi Nasional (KAN) dengan evaluator dari NMI negara lain yang terdaftar pada Asia Pasifik Metrologi Program (APMP).

Sistem penilaian kesesuaian sekarang ini telah ditangani secara serius oleh Komite Akreditasi Nasional (KAN) yang berkoordinasi dengan Badan Standardisasi Nasional (BSN) untuk masalah standar-standar yang terkait dengan hal tersebut. Dalam tulisan ini akan dibahas peran pengukuran, standardisasi, pengujian, dan jaminan mutu (MSTQ) dalam menunjang mutu produk dari segi pengukuran atau kalibrasinya, standar-standar yang digunakan untuk menunjang mutu terutama SNI, pengujian sebagai bukti bahwa SNI yang telah diterapkan terutama SNI wajib dapat menunjang mutu produk dan jaminan mutu produk melalui akreditasi dan sertifikasi. 


\section{LATAR BELAKANG DAN DASAR PEMBAHASAN}

Perkembangan kelembagaan MSTQ dimulai pertengahan tahun 80-an. Dengan telah dibentuknya Dewan Standardisasi Nasional yang sejak tahun 1995 menjadi Badan Standardisasi Nasional (BSN), implemetasi MSTQ telah berkembang serta terarah. Salah satu misi BSN adalah mengembangkan dan mendorong pendayagunaan Standar Nasional Indonesia (SNI). Sesuai dengan definisi standar yang diterbitkan oleh ISO (International Organization for Standardization) dan IEC (International Electrotechnical Commision), SNI diartikan sebagai dokumen yang berisikan ketentuan teknis, pedoman dan karakteristik kegiatan dan produk, yang disusun dan disepakati oleh pemangku kepentingan dan ditetapkan oleh BSN sebagai acuan yang berlaku secara nasional untuk membentuk keteraturan yang optimum dalam konteks keperluan tertentu.

\subsection{Perkembangan Perdagangan Dunia}

Persaingan internasional di bidang perdagangan menjadi semakin tajam. Elemen-elemen yang mendorong menajamnya persaingan tersebut adalah mutu produk, waktu penyerahan, jaminan purna jual, kepekaan akan minat konsumen, inovasi produk, agresifitas pemasaran, efisiensi dan efektifitas jaringan distribusi. Sampai saat ini perjanjian bilateral masih menjadi dasar terjadinya praktek perdagangan dan yang dijadikan ukuran adalah aturan dan standar yang berlaku di negara pengimpor. Globalisasi perdagangan telah memberikan penekanan lain, walau demikian kedudukan negara pengimpor masih tetap memegang peranan yang menentukan. Dalam putaran Uruguay tahun 1994 tentang hambatan teknis perdagangan (Technical Barrier to Trade - World Trade Organization (TBT-WTO) menyatakan bahwa dipersyaratkan adanya kompetensi teknis lembaga penilaian kesesuaian yang memadai di anggota yang melakukan ekspor, sehingga terdapat kepercayaan yang berkelanjutan dari hasil penilaian kesesuaian melalui verifikasi terhadap kesesuaian. Sebagai contoh, melalui akreditasi, dengan pedoman atau rekomendasi yang relevan, yang diterbitkan oleh lembaga standardisasi internasional harus dipertimbangkan sebagai indikasi kompetensi teknis yang memadai.

Informasi tentang standar dan penilaian kesesuaian untuk memfasilitasi perdagangan internasional dan domestik sangatlah diperlukan, sedangkan peran MSTQ untuk menunjang 36 standar dan penilaian kesesuaian adalah masalah penting yang tidak dapat diabaikan. Sejak tahun 1995 sampai saat ini tahun 2006 notifikasi standar yang telah dibuat oleh Indonesia baru 5 , sedangkan negara-negara di Asia Tenggara lainnya misalnya Thailand sudah menotifikasi 183, negara Malaysia menotifikasi 163 standar, dan Singapura menotifikasi 16 standar, yang artinya pengertian tentang implementasi perjanjian TBT di Indonesia relatif masih rendah.

Persyaratan dalam dunia perdagangan dan ketentuan baru dari WTO, mengakibatkan semua negara-negara industri mengembangkan sistem penilaian kesesuaiannya untuk dinyatakan secara internasional melalui perjanjian saling pengakuan atau Mutual Recognition Arrangement/Agreement (MRA). Meskipun MRA baru dapat berfungsi bila regulator dapat menerima hasil uji atau produk dari laboratorium atau organisasi yang kompeten di bidangnya. Dalam kondisi saat ini sistem penilaian kesesuaian di Indonesia masih perlu dikembangkan, selain terbatasnya tenaga ahli di bidang yang terkait dengan penilaian kesesuaian, juga masalah ketertelusuran pengukuran dan ketidakpastian pengukuran serta bahan acuan standar (Standard Reference Material - SRM), masih belum dapat diakui kompetensinya.

\subsection{Perkembangan Teknologi}

Dalam waktu kurang dari 25 tahun, Jepang telah berhasil meningkatkan citra produk industri mereka. Hal ini dimungkinkan berkat adanya dukungan pemerintah serta diterapkannya teknik-teknik baru dalam proses penciptaan nilai tambah, yang membuat mereka unggul dibandingkan Amerika dan negara-negara industri di Eropa.

Di negara-negara industri seperti halnya Jepang, Amerika dan Eropa, kegiatan MSTQ telah melekat menjadi bagian yang inherent dalam kehidupan industri mereka. Intensitas penerapan MSTQ telah dijadikan tolok ukur kemajuan teknologi dan industri suatu negara. Cina misalnya, perkembangan industri dinegara ini sangatlah cepat, produk-produk Cina banyak terdapat di Indonesia. Cina memperhitungkan mutu dari berapa lama konsumen akan menggunakan produk tersebut, bukan berapa lama produk tersebut bertahan, sehingga mutu produk disesuaikan terhadap lamanya konsumen dalam menggunakan produk tersebut. 


\section{KAJIAN TENTANG PENGUKURAN DAN PENGUJIAN DI INDONESIA}

Menghadapi kenaikan permintaan akan produk yang berkualitas dalam pasar internasional, suatu ekonomi memerlukan dukungan MSTQ yang efektif. Demi menjamin mutu, produsen memerlukan suatu laboratorium yang mempunyai tenaga kerja yang kompeten untuk mengerjakan pengendalian mutu dan pengujian di pabriknya.

Dengan adanya ISO/IEC Guide 25 yang telah diperbaharui menjadi ISO/IEC 17025 yang selaras dengan ISO 9000, yaitu tentang kompetensi yang harus dipatuhi oleh laboratorium penguji dan laboratorium kalibrasi, kegiatan pengukuran dan pengujian menjadi lebih terarah dan sistemnya dapat diakui secara internasional. Dalam ISO/IEC 17025 ini dijelaskan bahwa produk-produk yang dihasilkan oleh suatu laboratorium harus memenuhi hal-hal sebagai berikut: mempunyai personel yang kompeten, akomodasi dan kondisi lingkungan yang memadai, metode pengujian atau metode kalibrasi yang didokumentasikan dan divalidasi, peralatan dan/atau standar/bahan acuan yang memadai dan tertelusur, pengambilan sampel dan penanganan sampel uji atau barang yang dikalibrasi secara benar. Tentu saja semua hal di atas tidak dapat menjamin bahwa $100 \%$ produk sesuai persyaratan, karena kesalahan acak dan sistematik selalu ada (yang kemudian dikuantifikasi dalam bentuk ketidakpastian), dan juga kemungkinan terjadinya kekeliruan lainnya. Laboratorium-laboratorium dengan kegiatan mengacu pada ISO/IEC 17025 yang telah dakreditasi oleh KAN bertambah setiap tahunnya seperti terlihat pada Tabel 1.

Pada Tabel 1 berikut dapat dilihat penambahan laboratorium kalibrasi dan laboratorium penguji dari tahun 1998 sampai dengan akhir tahun 2005.

Tabel 1 Laboratorium Penguji dan Laboratorium Kalibrasi

\begin{tabular}{|c|r|r|r|r|r|r|r|r|}
\hline Tahun & $\mathbf{1 9 9 8}$ & $\mathbf{1 9 9 9}$ & $\mathbf{2 0 0 0}$ & $\mathbf{2 0 0 1}$ & $\mathbf{2 0 0 2}$ & $\mathbf{2 0 0 3}$ & $\mathbf{2 0 0 4}$ & $\mathbf{2 0 0 5}$ \\
\hline Laboratorium penguji & 45 & 63 & 78 & 117 & 158 & 186 & 239 & 301 \\
\hline Laboratorium kalibrasi & 17 & 21 & 32 & 46 & 51 & 58 & 66 & 81 \\
\hline
\end{tabular}

Sumber: Laporan Tahunan Komite Akreditasi Nasional

Data di atas tidak diperhitungkan laboratoriumlaboratorium yang telah dicabut status akreditasinya. Sebagai informasi sampai dengan tahun 2005, laboratorium penguji yang dicabut akreditasinya adalah sebanyak 35 laboratorium, sedangkan laboratorium kalibrasi sebanyak 3 laboratorium. Pencabutan ini didasarkan pada tidak dilakukannya perpanjangan status akreditasi karena kebakaran, gempa bumi dan lain-lain (misalnya di Aceh dan Bali).

\subsection{Pengukuran}

Pengukuran adalah bagian dari metrologi dan dalam MSTQ merupakan unsur yang pertama. Metrologi di Indonesia masih dalam taraf mencari identitas diri, yang artinya saat ini metrologi teknis dan metrologi legal masih berjalan sendiri-sendiri sesuai aturannya masingmasing. Sehingga masalah yang paling penting yaitu proses ketertelusuran pengukuran, belum dapat direalisasikan bersama. Namun demikian telah disepakati bahwa NMI Indonesia adalah Pusat Penelitian Kalibrasi Instrumentasi dan
Metrologi LIPI (Puslit KIM-LIPI), seperti yang telah dijelaskan di atas.

Pengukuran melalui kalibrasi masih relatif rendah di Indonesia, kegiatan ini dianggap tidak menguntungkan, sehingga perkembangan laboratorium kalibrasi amatlah lambat di Indonesia. Penyebarannyapun tidak merata, sebagai informasi sampai tahun 2005 laboratorium kalibrasi yang telah diakreditasi oleh KAN sebanyak 81 laboratorium seperti terlihat pada Tabel 1. Penyebaran laboratorium kalibrasi di DKI Jakarta dan Jawa Barat yang dapat dilihat pada Tabel 2, merata untuk semua bidang, terutama yang dikelola oleh swasta. Sedangkan di daerah lainnya tergantung pada adanya laboratorium penguji dan hanya bidang tertentu saja. Sebagai data terakhir penyebaran laboratorium kalibrasi beserta kemampuannya dalam bidang yang dapat laboratoriumlaboratorium tersebut lakukan adalah sebagai berikut (yang dimaksud instrumen analis disini adalah untuk bidang optik dan peralatan yang menggunakan Standard Reference Material (SRM) atau Certified Reference Material (CRM). 
Tabel 2 Penyebaran Labratorium Kalibrasi Beserta Bidangnya

\begin{tabular}{|c|c|c|c|c|c|c|c|c|c|c|c|c|c|c|c|c|c|c|}
\hline \multirow{2}{*}{$\begin{array}{c}\text { Propinsi } \\
\text { Kepemilikan }\end{array}$} & \multicolumn{3}{|c|}{ Dimensi } & \multicolumn{3}{|c|}{ Suhu } & \multicolumn{3}{|c|}{ Kelistrikan } & \multicolumn{3}{|c|}{ Massa } & \multicolumn{3}{|c|}{ Waktu } & \multicolumn{3}{|c|}{ Instrumen Analis } \\
\hline & $\mathbf{P}$ & B & $\mathbf{S}$ & $\mathbf{P}$ & B & $\mathbf{S}$ & $\mathbf{P}$ & B & $\mathbf{S}$ & $\mathbf{P}$ & B & $\mathbf{S}$ & $\mathbf{P}$ & B & $\mathbf{S}$ & $\mathbf{P}$ & B & $\mathbf{S}$ \\
\hline DKI Jakarta & 3 & 0 & 13 & 4 & 2 & 10 & - & 1 & 9 & 6 & 4 & 11 & - & - & 6 & 2 & - & 2 \\
\hline Jawa Barat & 5 & 3 & 5 & 7 & 2 & 4 & 3 & 5 & 4 & 6 & 3 & 7 & 1 & 4 & 3 & 4 & - & - \\
\hline Banten & 1 & 1 & 2 & 1 & 1 & 2 & 1 & 1 & 2 & 3 & 1 & 2 & - & - & 1 & - & - & 2 \\
\hline Jawa Tengah & 2 & - & 1 & 1 & 1 & 1 & - & - & 1 & 2 & 1 & 1 & - & - & - & - & - & 1 \\
\hline Jawa Timur & 1 & 1 & - & 1 & 2 & 1 & - & 2 & - & 3 & 1 & 1 & - & 2 & - & - & 1 & - \\
\hline Sumatra Utara & 1 & - & - & 1 & - & - & - & - & - & 1 & - & - & - & - & - & - & - & - \\
\hline Sumatra Barat & 1 & - & - & 1 & - & - & - & - & - & 1 & - & - & - & - & - & - & - & - \\
\hline Sumatra Selatan & - & - & - & - & 2 & - & - & - & - & - & 2 & - & - & - & - & - & 1 & - \\
\hline Batam / Riau & - & - & 1 & - & - & 1 & - & 1 & 2 & - & - & 2 & - & 1 & 1 & - & - & - \\
\hline Sulawesi Selatan & 1 & - & - & 1 & - & - & - & 1 & - & 1 & - & - & - & 1 & - & - & - & - \\
\hline Kalimantan Selatan & 1 & - & - & 1 & - & - & - & - & - & 1 & - & - & - & - & - & - & - & - \\
\hline Kalimantan Timur & - & 1 & - & - & - & - & - & - & - & - & - & - & - & - & - & - & - & - \\
\hline Jumlah & 16 & 5 & 22 & 18 & 10 & 19 & 4 & 9 & 18 & 24 & 12 & 24 & 1 & 8 & 11 & 6 & 2 & 5 \\
\hline
\end{tabular}

Keterangan: $\mathrm{P}=$ Pemerintah; $\mathrm{B}=\mathrm{BUMN}$; $\mathrm{S}=$ Swasta

Sumber: Direktori Komite Akreditasi Nasional

\subsection{Pengujian}

Pengujian dalam MSTQ merupakan bagian penting, dengan adanya pengujian terhadap suatu produk tertentu dapat dilihat mutu dari produk-produk tersebut. Pertumbuhan laboratorium penguji yang diakreditasi oleh KAN berkembang pesat. Perkembangan ini disebabkan oleh ketentuan bahwa laboratorium penguji yang melaksanakan SNI wajib harus sudah diakreditasi. Dalam Tabel 1 dapat dilihat pertambahan laboratorium penguji, terutama untuk tahun-tahun terakhir, penambahan cukup tinggi antara $50-100$ laboratorium. Bidangbidang kegiatan dari laboratorium penguji yang telah diakreditasi oleh KAN, lebih banyak bidang atau sektor dimana laboratorium-laboratorium tersebut berada, misalnya di Jakarta, sektor industri lebih banyak dibandingkan daerah lain. Di Jawa Barat, sektor pertanian lebih mendominasi. Sebagai data terakhir tentang penyebaran laboratorium penguji beserta kemampuannya dalam bidang yang dapat laboratorium-laboratorium tersebut lakukan adalah sebagai berikut:

Tabel 3 Penyebaran Labratorium Penguji Beserta Bidangnya

\begin{tabular}{|c|c|c|c|c|c|c|c|c|c|c|c|c|c|c|c|}
\hline \multirow{2}{*}{$\begin{array}{c}\text { Propinsi } \\
\text { Kepemilikan }\end{array}$} & \multicolumn{3}{|c|}{ Perikanan } & \multicolumn{3}{|c|}{ Pangan } & \multicolumn{3}{|c|}{ Pertanian } & \multicolumn{3}{|c|}{ Lingkungan } & \multicolumn{3}{|c|}{$\begin{array}{c}\text { Pertambangan } \\
\text { Atau } \\
\text { Energi }\end{array}$} \\
\hline & $\mathbf{P}$ & B & $\mathbf{S}$ & $\mathbf{P}$ & B & $\mathbf{S}$ & $\mathbf{P}$ & B & $\mathbf{S}$ & $\mathbf{P}$ & B & $\mathbf{S}$ & $\mathbf{P}$ & B & $\mathbf{S}$ \\
\hline DKI Jakarta & 3 & - & - & 9 & 1 & 1 & 5 & - & - & 5 & 1 & 5 & 11 & 3 & 1 \\
\hline Jawa Barat & 2 & - & - & 8 & 2 & 6 & 12 & 1 & 1 & 12 & 5 & 5 & 7 & 2 & 2 \\
\hline Banten & 1 & - & - & 1 & - & - & 1 & - & - & 2 & - & - & 1 & - & - \\
\hline Jawa Tengah & 5 & - & - & 2 & - & 1 & 2 & 2 & 1 & 6 & 1 & - & 1 & 2 & - \\
\hline Jawa Timur & 2 & - & - & 3 & 1 & 1 & 4 & - & 1 & 2 & 1 & 1 & 2 & 1 & - \\
\hline DI Yogyakarta & - & - & - & 1 & - & - & 1 & - & - & 1 & - & - & - & - & - \\
\hline Sumatra Utara & 1 & - & - & 3 & - & 1 & 4 & - & - & 4 & - & - & - & - & - \\
\hline Sumatra Barat & 1 & - & - & 2 & - & - & 2 & - & - & 1 & - & - & - & - & 2 \\
\hline Sumatra Selatan & 2 & - & - & 2 & 1 & - & 2 & - & - & 4 & 1 & - & - & 5 & - \\
\hline Riau & 1 & - & - & 3 & - & 2 & 1 & - & - & 1 & - & - & - & 1 & - \\
\hline Bengkulu & 1 & - & - & 1 & - & - & 1 & - & - & - & - & - & - & - & - \\
\hline Lampung & 2 & - & - & 1 & - & - & 1 & 1 & 2 & 1 & - & - & - & 2 & - \\
\hline Jambi & 1 & - & - & 2 & - & - & 1 & - & - & - & - & - & - & - & - \\
\hline
\end{tabular}




\begin{tabular}{|c|c|c|c|c|c|c|c|c|c|c|c|c|c|c|c|}
\hline \multirow{2}{*}{$\begin{array}{c}\text { Propinsi } \\
\text { Kepemilikan }\end{array}$} & \multicolumn{3}{|c|}{ Perikanan } & \multicolumn{3}{|c|}{ Pangan } & \multicolumn{3}{|c|}{ Pertanian } & \multicolumn{3}{|c|}{ Lingkungan } & \multicolumn{3}{|c|}{$\begin{array}{c}\text { Pertambangan } \\
\text { Atau } \\
\text { Energi }\end{array}$} \\
\hline & $\mathbf{P}$ & B & $\mathrm{S}$ & $\mathbf{P}$ & B & S & $\mathbf{P}$ & B & $\mathbf{S}$ & $\mathbf{P}$ & B & $\mathbf{S}$ & $\mathbf{P}$ & B & $\mathbf{S}$ \\
\hline Bangka Belitung & - & - & - & - & - & - & - & - & - & - & - & 1 & - & - & 1 \\
\hline Sulawesi Selatan & 4 & - & - & 3 & - & - & 1 & - & 3 & 1 & - & - & - & 2 & - \\
\hline Sulawesi Utara & 2 & - & - & 2 & - & - & - & 1 & - & - & - & - & - & - & - \\
\hline Sulawesi Tengah & - & - & - & 1 & - & - & 1 & 1 & - & - & - & - & - & - & - \\
\hline Sulawesi Tenggara & 1 & - & - & 1 & - & - & 1 & -- & - & - & 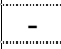 & - & - & - & - \\
\hline Maluku & - & - & - & 1 & - & - & - & - & - & - & - & - & - & - & - \\
\hline Kalimantan Selatan & 1 & - & - & 2 & - & - & 1 & - & 1 & 1 & 1 & - & 1 & 1 & 2 \\
\hline Kalimantan Timur & 2 & - & - & 2 & - & - & - & - & - & 1 & 1 & - & - & 6 & 1 \\
\hline Kalimantan Tengah & 1 & - & - & 1 & - & - & - & - & - & 1 & - & - & - & - & - \\
\hline Kalimantan Barat & 2 & - & - & 4 & - & - & 1 & - & - & 1 & - & - & - & - & - \\
\hline Bali & 2 & - & - & 1 & - & - & 1 & - & - & - & - & - & - & - & - \\
\hline NTB & - & - & - & 1 & - & - & - & - & - & 1 & - & - & - & - & - \\
\hline NTT & 1 & - & - & - & - & - & - & - & - & - & - & - & - & - & - \\
\hline Irian Jaya & 3 & - & - & 2 & - & - & 1 & 1 & - & - & - & 1 & & & \\
\hline Jumlah & 41 & - & - & 59 & 5 & 12 & 44 & 7 & 9 & 45 & 11 & 13 & 23 & 25 & 9 \\
\hline
\end{tabular}

Keterangan: $\mathrm{P}=$ Pemerintah; $\mathrm{B}=\mathrm{BUMN} ; \mathrm{S}=$ Swasta

Sumber : Direktori Komite Akreditasi Nasional

\section{KAJIAN TENTANG STANDARDISASI DAN JAMINAN MUTU}

\subsection{Standardisasi}

Dengan adanya Sistem Standardisasi Nasional (SSN) melalui PP 102 yang dikembangkan oleh BSN sebagai landasan kerja standardisasi yang mencakup standar, penilaian kesesuaian dan regulasi teknis seperti terlihat pada Gambar 1. BSN juga memfasilitasi pembentukan dan perkembangan kelembagaan yang terkait dengan sistem standardisasi nasional dan mengembangkan kebijakan dan pedoman di bidang standardisasi untuk memandu pelaksanaan semua proses standardisasi.

Penggunaan SNI di laboratorium, terutama SNI wajib banyak dilaksanakan oleh laboratorium-laboratorium penguji milik pemerintah, karena peraturan ini lebih banyak ditujukan untuk produk-produk yang diatur oleh pemerintah. Dari Direktori KAN tahun 2005, tercatat 184 laboratorium yang telah diakreditasi, yang menggunakan SNI sebanyak 103 laboratorium dan kesemuanya dilakukan oleh laboratorium penguji, sedangkan lainnya menggunakan ASTM, AOAC, APHA terutama untuk sektor-sektor yang berkaitan dengan uji kimia. Lain halnya dengan laboratorium kalibrasi, kegiatan laboratorium kalibrasi belum ada yang menggunakan SNI karena belum ada SNI tentang kegiatan kalibrasi. Sebagian besar malah menggunakan pengembangan sendiri berdasarkan pegalaman kemudian dilakukan uji banding dengan menggunakan metode pengembangan sendiri ini. Metode kalibrasi seharusnya berisi model matematis, analisis data, ketidak pastian, cara pelaporan, dan intrepretasi hasil, dan sampai saat ini hanya beberapa yang berisi seperti itu (sebagai contoh dari ASTM, Australian Standard). Sebagian besar lebih banyak mengatur mengenai spesifikasi untuk suatu peralatan dan langkahlangkah pengukuran yang diperlukan untuk menilai kesesuaian terhadap spesifikasi tersebut. Sehingga dalam menilai kompetensi personel dalam melakukan kalibrasi akan berbeda dari satu asesor terhadap asesor lainnya, tergantung dari cara melihat asesor tersebut terhadap spesifikasi yang diinginkan laboratorium. Sehingga Uji bading antar laboratorium sangat diperlukan sekali untuk menilai kompetensi personel dalam melaksanakan kalibrasi, dalam hal ini standar acuan selalu dianggap benar atau hasil kalibrasi yang dilakukan oleh laboratorium acuan dianggap sebagai nilai benar. Sehingga metode kalibrasi setiap laboratorium akan berbeda tergantung dari standar acuan yang digunakan. 


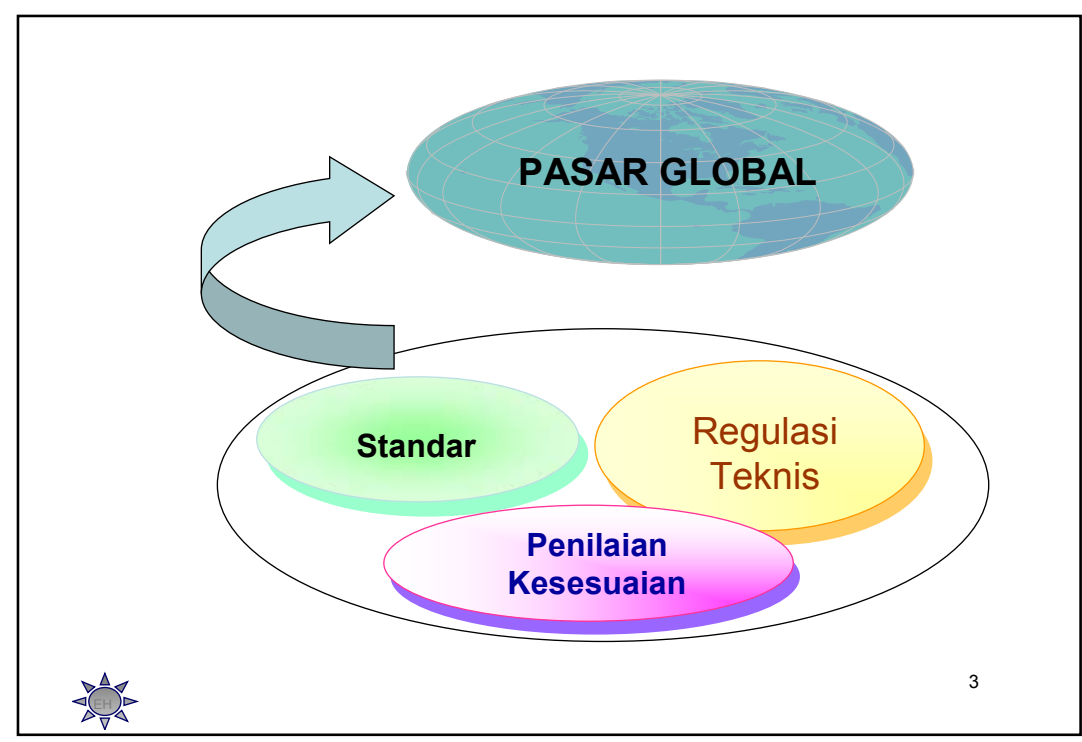

Gambar 1 Sistem Standardisasi Nasional

\subsection{Jaminan Mutu}

Agar produk yang dihasilkan sesuai seperti yang diinginkan dalam pasar internasional, perlu adanya acuan atau standar baik itu di bidang hasil produk atau peralatan yang dipunyainya.

Dalam ISO/IEC 17025 tentang jaminan mutu dapat dijelaskan bahwa jaminan mutu merupakan semua kegiatan yang terencana dan sistematis, yang diperlukan untuk memberikan keyakinan bahwa produk yang dihasilkan akan memenuhi kebutuhan.

Kontribusi masing-masing faktor yaitu personel, lingkungan, metode dan peralatan mempunyai kontribusi dalam menentukan ketidakpastian pengukuran, dan ketidakpastian tersebut berbeda pada (jenis dari) pengujian yang satu dan yang lainnya dan pada (jenis dari) kalibrasi yang satu dan yang lainnya. Laboratorium harus memperhitungkan faktorfaktor tersebut dalam mengembangkan metoda dan prosedur pengujian dan kalibrasi, dalam pelatihan dan kualifikasi personel, dan dalam pemilihan dan kalibrasi peralatan yang digunakan.

Seperti yang telah dinyatakan di atas bahwa Institusi Metrologi Nasional di Indonesia adalah Puslit KIM-LIPI yang merupakan lembaga yang berfungsi untuk mengembangkan infrastruktur metrologi yang mencakup penyediaan dan pemeliharaan Standar Nasional Satuan Ukuran (SNSU). SNSU adalah standar satuan ukuran yang memiliki nilai ketidakpastian terkecil di Indonesia dan dapat ditelusuri ketertelusurannya melalui rantai tak terputus ke standar primer. Fungsi lain dari Puslit KIM-LIPI adalah mendiseminasikan standar satuan ukuran, mengembangkan berbagai kompetensi di bidang metrologi untuk pengembangan standar satuan ukuran, metoda kalibrasi dan pengukuran. Dalam APLAC MR 002 tentang NMI dan ketertelusuran dinyatakan bahwa kepercayaan laboratorium-laboratorium dan lembaga inspeksi tentang ketertelusuran yang diklaimnya ke NMI yang telah diakreditasi dan sebagai penunjang kegiatan BIPM dan organisasi metrologi regional. Dan dalam ILAC P-10 dinyatakan bahwa informasi tentang NMI yang diperlukan oleh badan akreditasi untuk mendemonstrasikan ketertelusuran bagi laboratorium-laboratorium yang telah diakreditasinya telah dipublikasikan dalam Appendix C of the CIPM MRA.

Sampai saat ini Puslit KIM-LIPI sebagai NMI Indonesia telah terdaftar di Apendix C BIPM untuk bidang kelistrikan, sebagai suatu syarat MRA KAN di APLAC/ILAC, sedangkan untuk bidang massa, suhu, tekanan dan dimensi masih dievaluasi oleh Joint Committee of Regional Metrology Bodies (JCRB)

\section{PEMBAHASAN}

\subsection{Pengukuran dan Pengujian}

\subsubsection{Laboratorium Kalibrasi}

Pengukuran yang dilakukan oleh laboratorium kalibrasi, masih banyak tersebar di daerah Jakarta dan Jawa Barat. Peralatan-peralatan yang memerlukan kalibrasi terbanyak adalah pada bidang massa, suhu dan dimensi. 
Sedangkan bidang lain misalnya kelistrikan, hanya sebagian kecil industri ini yang mempunyai peralatan ukur kelistrikan untuk dikalibrasi, sehingga laboratorium kalibrasi ini lebih banyak menunjang organisasi induknya. Hal ini dapat dilihat dari sertifikat yang diterbitkan oleh laboratorium-laboratorium tersebut. Demikian juga untuk laboratorium kalibrasi, selain di DKI dan Jawa Barat, laboratoriumlaboratorium tersebut lebih banyak untuk menunjang organisasi induknya, sehingga bidang yang dapat dikalibrasipun tergantung pada kebutuhan organisasi induknya atau peralatan ukur yang dipunyai oleh laboratorium penguji yang terdapat diderahnya.

Laboratorium-laboratorium kalibrasi, melakukan kalibrasi terhadap peralatan ukurnya lebih banyak ke NMI Indonesia, atau ke laboratorium kalibrasi lain yang mempunyai peralatan standar dengan ketelitian lebih tinggi, dengan konsekuensi mempunyai ketidakpastian yang akan lebih besar.

\subsubsection{Laboratorium Penguji}

Dari Tabel 3, dapat dilihat bahwa laboratorium penguji yang telah diakreditasi oleh KAN lebih banyak milik pemerintah. Hal ini disebabkan adanya penunjukkan dari pemerintah untuk melaksanakan SNI wajib, dengan kata lain laboratorium yang ditunjuk untuk melaksanakan SNI wajib harus sudah diakreditasi oleh KAN. Kegiatan pengujian yang dilakukan tergantung dari daerahnya, pada sektor perikanan merata di semua daerah di Indonesia, kecuali untuk Daerah Istimewa Yogyakarta, Bangka Belitung, Sulawesi Tengah, Maluku dan NTB. Keseluruhan dari laboratorium tersebut adalah milik pemerintah. Sedangkan sektor industri seperti telah dijelaskan di atas, DKI Jakarta dan Jawa Barat lebih mendominasi, demikian juga pertanian, daerah Jawa Barat lebih banyak di bandingkan daerah-daerah lainnya. Untuk sektor pertanian ini, didaerah perkebunan kopi, misalnya di Sulawesi, maka laboratorium penguji lebih banyak untuk kegiatan pengujian kopi. Jadi sektor pertanian yang dimaksud dalam Tabel 3 adalah kegiatan laboratorium penguji dimana laboratorium penguji tersebut berada, bukan berarti laboratorium penguji tersebut mampu menguji seluruh sektor pertanian. Sedangkan sektor lainnya hampir merata diseluruh Indonesia, kecuali untuk klinik dan kelistrikan. Pengujian untuk kelistrikan hanya berada di pulau Jawa, disebabkan karena industri bidang ini hanya ada di Jawa dan barang-barang elektronik lebih banyak masuk melalui Tanjung Priuk atau Jakarta.
Laboratorium-laboratorium penguji melakukan kalibrasi peralatan ukurnya melalui laboratoriumlaboratorium kalibrasi dari organisasi induknya, misalnya laboratorium-laboratorium di bawah Badan Pengawasan Obat dan Makanan (BPOM) di seluruh Indonesia, mengkalibrasikan peralatan ukurnya lebih banyak ke Pusat Pengawasan Obat dan Makanan (PPOM) Jakarta. Demikian juga untuk laboratorium-laboratorium di bawah Departemen Perdagangan, lebih banyak ke laboratorium kalibrasi yang terdapat d bawah Departemen Perdagangan.

\subsection{Sistem Standardisasi Nasional dan Jaminan Mutu}

Standardisasi dalam mendukung jaminan mutu produk dapat dicapai dengan telah berfungsinya sistem pengujian yang beracuan pada SNI, dan Lembaga Sertifikasi Produk yang mulai berkembang dengan sistem yang telah diterapkan oleh Komite Akreditasi Nasional (KAN). KAN sebagai salah satu lembaga penilaian kesesuaian, disamping lembagalembaga sertifikasi lain yang mempunyai kepentingan demi perkembangan standar itu sendiri. Standar yang dimaksud di atas termasuk $\mathrm{SNI}$, tentu disini diharapkan adalah SNI sebagai tuan rumah perkembangan standar di Indonesia.

Lembaga penilaian kesesuaian, khususnya laboratorium penguji maupun laboratorium kalibrasi, harus secara periodik mengkalibrasikan peralatan ukurnya, agar dapat diketahui ketidak pastian pengukurannya. Hal ini juga untuk menjaga ketertelusuran peralatan ukur tersebut. Dalam ketertelusuran pengukuran laboratorium kalibrasi yang telah diakreditasi oleh KAN merupakan pilihan yang tepat untuk mengkalibrasikan peralatan ukur milik lembaga penilaian kesesuaian, karena laboratoriumlaboratorium kalibrasi tersebut sudah dibuktikan melalui akreditasi bahwa mereka tertelusur ke SI melalui Institusi-institusi metrologi nasional.

\section{KESIMPULAN}

6.1 Sampai saat ini laboratorium kalibrasi yang tersebar di Indonesia lebih banyak di Jakarta dan Jawa Barat, hanya bidangbidang tertentu yang terdapat di daerah tergantung pada kegiatan terbanyak di daerah tersebut.

6.2 Demikian juga laboratorium penguji, kegiatan yang dilakukan tergantung dimana laboratorium tersebut berada, misalnya sektor pertanian, laboratorium penguji yang berada di sektor pertanian 
kopi atau coklat atau lainnya, akan melakukan pengujian sesuai komoditi daerahnya.

6.3 Laboratorium-laboratorium kalibrasi lebih banyak menggunakan metode pengembangan sendiri, terutama untuk kelistriak. Hal ini disebabkan karena dokumen-dokumen tentang kegiatan kalibrasi lebih banyak mengacu pada specifikasi alat ukur. Yang dapat dianggap sebagai metode kalibrasi hanya beberapa standar acuan saja misalnya ASTM E 542 atau AS 2162 untuk volumetric glassware.

6.4 Pelaksanaan SNI wajib lebih banyak dilaksanakan oleh laboratoriumlaboratorium penguji milik pemerintah, karena adanya penunjukan dari Menteri terkait untuk melaksanakan SNI wajib.

6.5 Perkembangan standar nasional, pelaksanaan penilaian kesesuaian, dan pemberlakuan standar wajib yang digunakan oleh regulator berkaitan dengan transaksi perdagangan internasional, secara regional atgkungan yanional, harus didukung dengan kebijakan yang mengacu pada norma dan ketentuan yang disepakati melalui PBB, WTO, lembaga standar internasional dan kerja sama antar lembaga akreditasi, serta melalui kerja sama regional melalui APEC dan ASEAN.

\section{DAFTAR PUSTAKA}

1. Herudi Kartowisastro (1991), Sistem MSTQ Nasional Prasyarat Industrialisasi, KIPNAS V, Jakarta.

2. Herudi Kartowisastro, Setyodewati (1991), Peran Kalibrasi, Instrumentasi, dan Metrologi dalam Usaha Peningkatan Mutu, Simposium Metode Metrologi dalam Meningkatkan Kemampuan Bersaing Kualitas Produk Indonesia, Jakarta

3. Direktori Laboratorium, Lembaga Inspeksi dan Lembaga Sertifikasi yang telah dikareditasi oleh Komite Akreditasi Nasional - 2005

4. ISO/IEC 17025:2005: General Requirements for the competence of testing and calibration laboratories.

5. ILAC-P10:2002, ILAC Policy on Traceability of Measuement Result, ILAC Publication.

\section{BIODATA}

Ir. Setyodewati, M.Eng.Sc., saat ini bekerja di Pusat Akreditasi Laboratorium dan Lembaga Inspeksi, Badan Standardisasi Nasional. Penulis menyelesaikan pendidikan S2 bidang Optoelektronika dan Aplikasi Laser di Universitas Indonesia, Jakarta. 